\title{
Technical Evaluation of Uptake, Use, Management and Future Implications of Household Biogas Digesters-A Case of Kampala City Peri-Urban Areas
}

\author{
Peter Tumutegyereize ${ }^{1,2 *}$, Clever Ketlogetswe ${ }^{1}$, Jerekias Gandure ${ }^{1}$, Noble Banadda ${ }^{2}$ \\ ${ }^{1}$ Department of Mechanical Engineering, University of Botswana, Gaborone, Botswana \\ ${ }^{2}$ Department of Agricultural and Biosystems Engineering, Makerere University, Kampala, Uganda \\ Email: ^ptumutegyereize@caes.mak.ac.ug
}

How to cite this paper: Tumutegyereize, P., Ketlogetswe, C., Gandure, J. and Banadda, N. (2017) Technical Evaluation of Uptake, Use, Management and Future Implications of Household Biogas DigestersA Case of Kampala City Peri-Urban Areas. Computational Water, Energy, and Environmental Engineering, 6, 180-191. https://doi.org/10.4236/cweee.2017.62013

Received: October 6, 2016

Accepted: March 25, 2017

Published: March 28, 2017

Copyright $\odot 2017$ by authors and Scientific Research Publishing Inc. This work is licensed under the Creative Commons Attribution International License (CC BY 4.0).

http://creativecommons.org/licenses/by/4.0/ (c) (i) Open Access

\begin{abstract}
The purposes for which biogas technology was introduced at household level were multiple but the major and direct one was to provide a clean and sustainable energy, thereby reducing the reliance on wood fuel. From the socio-economic studies that have been carried out, biogas end-users and technicians continue to be blamed for technical factors hindering its adoption and use. However, the ways these factors hinder biogas adoption and use plus the linkage between them seem not well understood right from policy to endusers. A technical survey was carried out on household biogas digesters to evaluate the adoption, use and management factors and their implications on the future of household digesters. Over-designed digesters in relation to family size yet not producing enough biogas, dependence on cow dung as the feedstock, $75 \%$ of users not being sure of loading rate and mixing ratios, not feeding the digesters daily by all households were found to be the main causes of why biogas was not enough for $87.5 \%$ of the respondents and digesters were abandoned in Kampala, Uganda. All surveyed digesters were characterized by starvation-overfeeding problem. Wood fuel was found still dominating in these households with biogas. Given that end-users had no options of digester types from which to select, but handed-over with over-size fixed dome digesters, there is need for all biogas stakeholders to come together as the reality on ground reveals that right from inception to management, everyone is to blame for the technical failures.
\end{abstract}

\section{Keywords}

Biogas Technology, Wood Fuel, Policy, Feedstock, Technical Failures 


\section{Introduction}

In the need to provide sustainable clean energy to the ever growing population, biogas technology has been seen as one of the renewable energy sources that can cause a paradigm shift on communities, especially in the developing countries. However, its adoption and use seem not to be advancing in most of these developing countries where it was hoped to have an impact. This has led to a number of researchers to carry out in-depth studies on socio-economic factors hindering biogas adoption and use with little on technical factors where biogas users and technicians are always blamed [1] [2]. Tumwesige [3] reviewed biogas appliances as one of the technical factors hindering biogas performance usage. However, before the appliances, there are a number of other technical factors that if not considered the appliance will perform poorly however much perfect it might be. Such technical factors include how much is fed into the digester per unit time (loading rate), number of times the digester is fed, mixing ratio of water and the substrate at hand as well as the ratios between substrates where more than one is being used, digester size and type and available substrate among others. These and more continue to be silent technical factors which seem to be not well understood right from policy to end-users in ways how they hinder biogas adoption and use plus the linkage between them, but have received little attention from researchers. In Uganda, biogas-users complain that biogas takes a lot of time to make a meal ready [4]. Although the low heating value of biogas plays a part in this which is a natural characteristic, technical factors are also partly responsible. Rajendran [5] recommended research into why people stop using household biogas digesters due to lack of knowledge, low gas production and inadequate supply of substrate. In regard to inadequate substrate supply, Balana and Glenk [6] suggested designs whose capacity can be changed to match the reduction in substrate. This seems to be unattainable in the near future. Therefore, the aim of this work was to evaluate technical factors right from adoption, use, management and their implications on the future of household biogas digesters. The intention is to inform and guide policy when planning, implementing and managing biogas projects.

\section{Materials and Methods}

\subsection{Questionnaire Design}

To carry out the technical evaluation, a questionnaire was designed for households with biogas digesters either working or not working. The questionnaire was divided into five sections. The first part was intended to capture demographic information and resources available that directly or indirectly affect the type and size of the biogas digester. The next section considered biogas systems and status. The third section looked at information related to biogas use practices and behaviour that help to understand the potential of the digester to supply the needed energy as well as the safety of the users. The fourth section collected data on operation and management practices that influence the efficiency of di- 
gesters. The last section was meant for digesters that were not working. The questionnaire was pretested and administered in two divisions in Kampala city and two sub-counties in Wakiso district neighbouring Kampala city that had been selected randomly. The study intended to have at least five households with biogas digesters from each of the selected divisions to make twenty in total. However, only ten in total were found basing on the informers in each of the selected divisions. Figure 1 represents the map of Kampala city and Wakiso district showing their respective divisions and the respective locations (marked with red pins) of the household biogas digesters from which data was collected. These locations were mapped using Geographical Information System (GIS) tools.

\subsection{Data Analysis}

Statistical Package for Social Sciences (SPSS) was used in data entry and analysis. Descriptive statistical analysis using frequencies was applied to questions that needed one response while for questions that necessitated multiple responses, multiple response analysis was used.

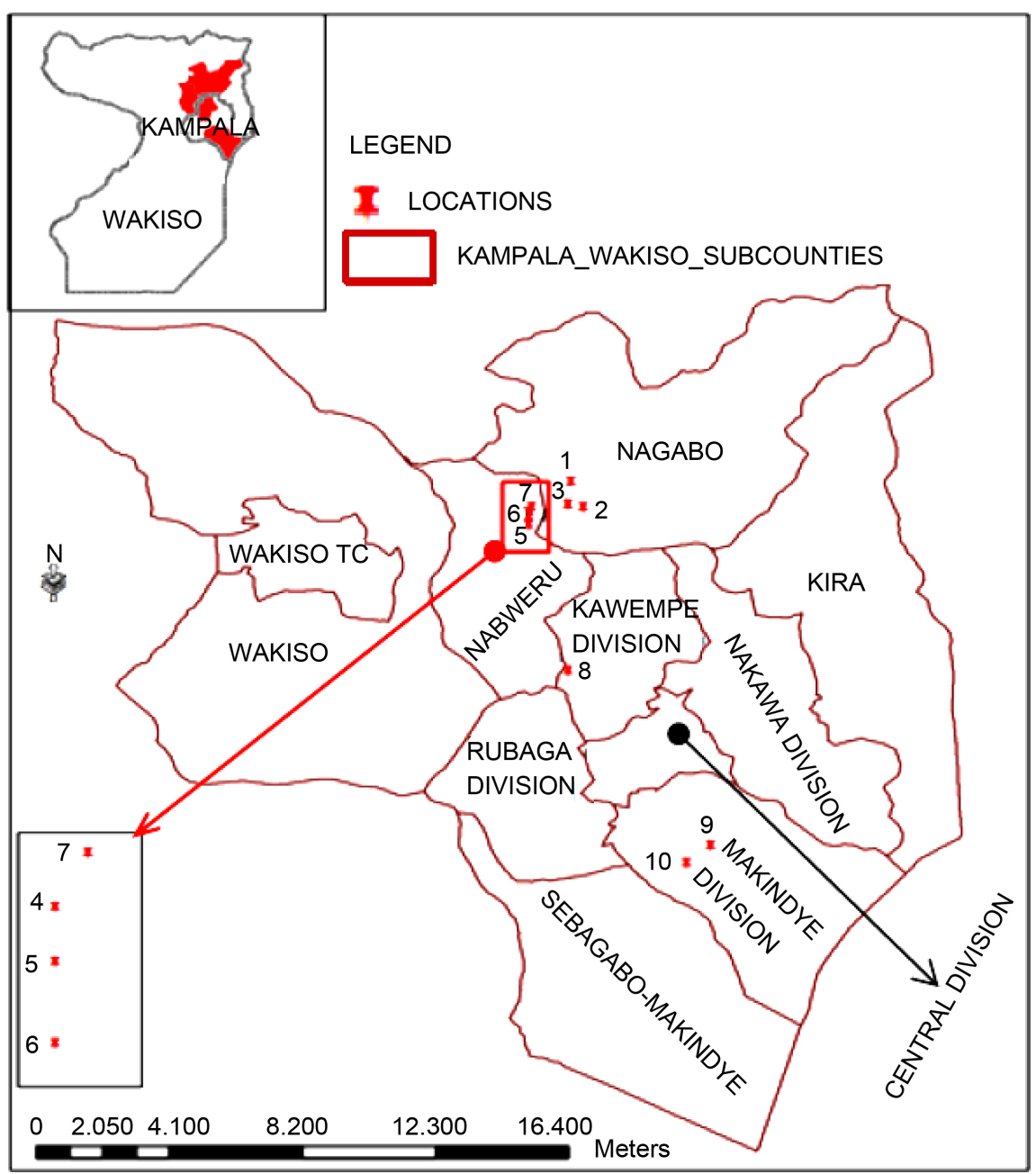

Figure 1. Map showing locations marked with red pins of the surveyed biogas digesters. 


\section{Results and Discussion}

\subsection{Factors That Influence Biogas Technical Performance at Adoption Level}

Figure 2 and Figure 3 show results on demographic data in relation to the digester size, type of feedstock and implementers. From this study it was revealed that households with biogas digesters are those headed by people who have retired or yet to retire. This is evidenced by the $87.5 \%$ of the respondents in age bracket of greater than 55 years. Considering their education level, over $80 \%$ had attained tertiary education and secondary both combined. Age and education level are indicators of one's potential to participate in making choices and decisions. It was found that for all the respondents, the type of digester being used is a fixed dome. On asking whether they had participated in selecting the digester type of their choice, none of the respondents was sure or aware of the other types of biogas digesters. With over $40 \%$ of the total respondents having attained tertiary education and over $40 \%$ secondary education as already shown in Figure 2, their failure to participate in the selection of the digester type of their choices

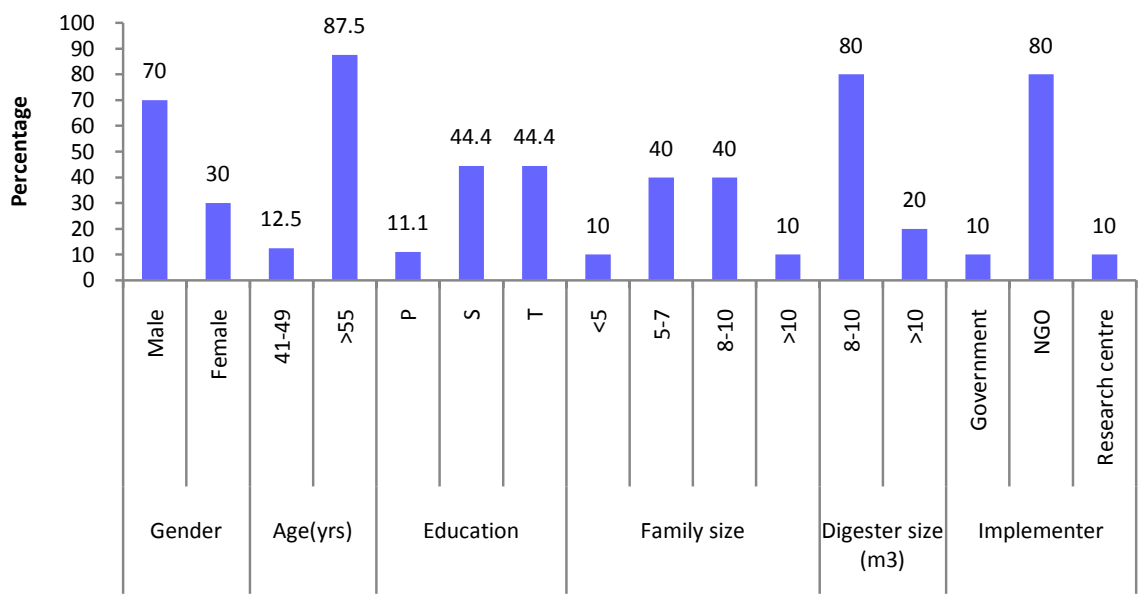

Figure 2. Factors that influence household biogas systems. NB: P-Primary, S-Secondary, T-Tertiary.

Percentage share of feedstock being used

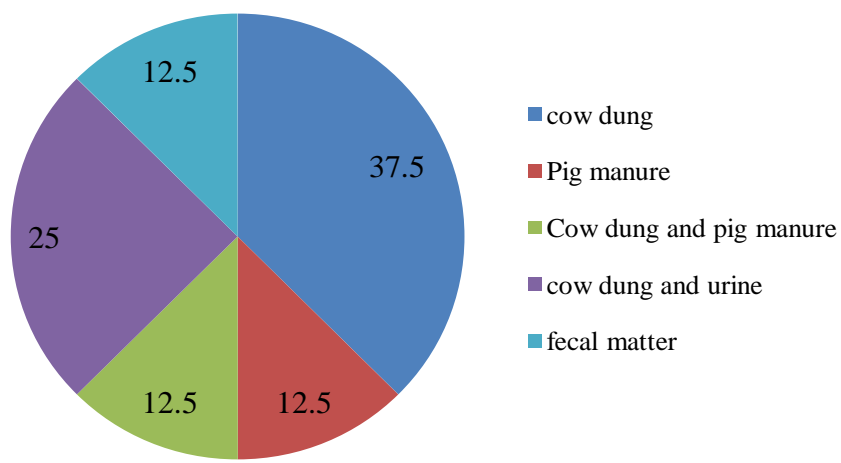

Figure 3. Percentage share of feedstock being used in household biogas digesters. 
implies total disregard by the biogas implementers (government, NGOs and research centres) in involving the users or community. As it can be seen in Figure 3, $80 \%$ of the digesters were implemented by NGOs while government and research centres were responsible for $10 \%$ each. Among the presented factors, family size is the most important that directly determines the size of digester to be constructed as shown in Equation (1).

$$
V=F_{s} \times p_{b} / v_{r}
$$

where, $V$ is the volume of digester $\left(\mathrm{m}^{3}\right), F_{s}$ is family size, $p_{b}$ is per capita biogas usage $\left(\mathrm{m}^{3} / \mathrm{d}\right)$ and $v_{r}$ is volumetric biogas production rate $\left(\mathrm{m}^{3} / \mathrm{m}^{3} \cdot \mathrm{d}\right)$. From these results digester size and family size were found not to have any relationship given that $80 \%$ of the digesters were of $8 \mathrm{~m}^{3}$ while family size varied mainly from 5 to 10. This is an indication of either over design or under design as the demand (family size) does not march with the size of digester. However, Rajendran [5] suggested that a digesters size of $6 \mathrm{~m}^{3}$ is enough to supply biogas sufficient for a family of 9 people. Therefore, going by this, one can say that majority of the household digesters surveyed were over designed. Again, this technical fault of over design can be blamed on the side of the implementer. The implementer is group of people with knowledge and skill about biogas representing an entity (government, NGO or research centre). This group of people with knowledge and skill include policy makers, social workers, economists, scientists, engineers and technicians or masons among others. The sad note is that almost all studies on technical failures hindering biogas adoption, use and management have always blamed the technicians who in most cases are the masons and biogas users [1] [2] [5]-[11]. The people who do research to know how digester size, family size and available feedstock are related in affecting biogas performance are scientists and engineers.

A household using a mixture of cow dung and pig manure or more than one feedstock will never know the optimal ratio that favours anaerobic process for maximum biogas/methane unless the researcher comes in the equation. This is in light of the much available literature on synergetic effect of co-digestion on methane yield with little mention on the antagonistic effects [12] [13] [14]. From Figure 3, it can be seen that diversity in feedstock available is limited with cow dung dominating. This has negative consequences on wide spread adoption and continuity of the technology. Such consequences include among others households without animal may not adopt and digester abandonment in case of reduction in number or death of animals leading to shortage in feedstock supply.

\subsection{Factors That Influence Technical Performance during Usage of Biogas}

Figure 4 shows results on the status of the digesters that were surveyed and the satisfaction of the users in terms of time of use, what biogas is used for and whether it is sufficient or not. It was found that $90 \%$ of the surveyed digesters were working. Those not working represented by $10 \%$ were as a result of abandonment resulting from lack of feedstock after the animals died. As already 


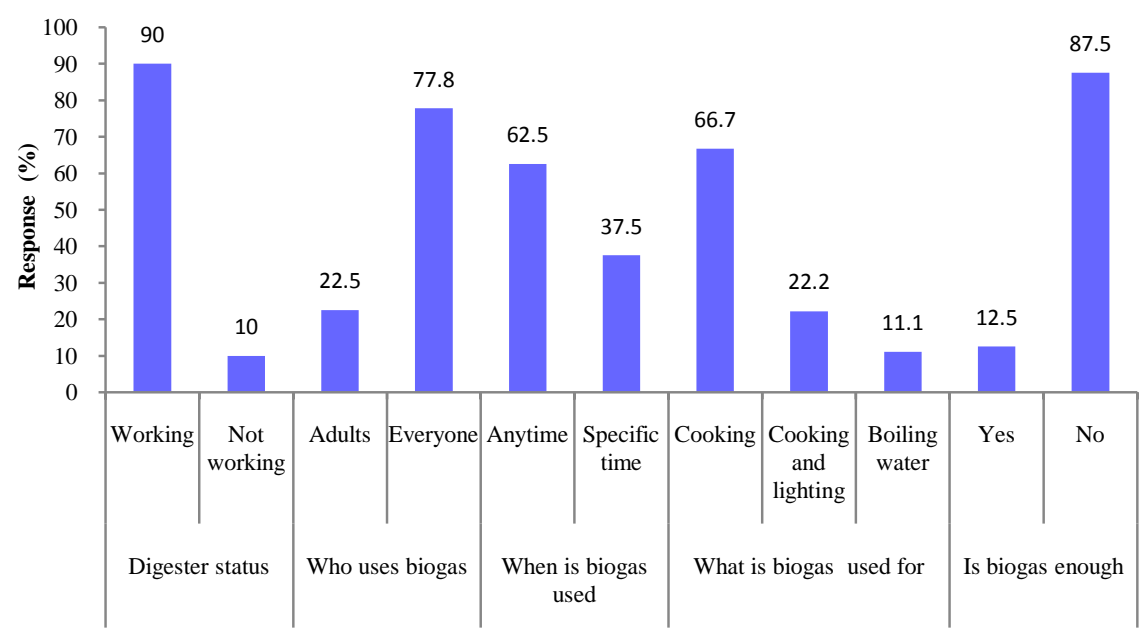

Figure 4. Digester and user status.

explained in Section 3.1, limited diversity in feedstock supply presents great challenges on the continuity of biogas digesters. The question who uses biogas was asked to understand the level of responsibility in energy saving. A worker or children may switch on the stove before cooking pot is ready fail to switch off the stove immediately after cooking. This contributes to biogas not being enough for the task. Results show that over $75 \%$ of the households, everyone is free to use biogas which is good. However, this compromises on energy saving unless the techniques of energy saving are emphasized. Another important factor was the freedom to use biogas anytime of the day represented by $62.5 \%$. This is an indication that these digesters had a potential to supply most of the energy requirements of these households, if not all. Majority of the households (66.7\%) were found to be using biogas for cooking while $22.2 \%$ use it for both cooking and lighting and $11.1 \%$ use it only for boiling water. Diversifying biogas applications has been suggested by some researchers [6], However, this can only be possible that there is more than enough for cooking and lighting. The big question on whether biogas was enough or not, clearly showed that biogas was not enough represented by $87.5 \%$. Only $12.5 \%$ of the respondents acknowledged that biogas was enough which also corresponds with the $10 \%$ using biogas alone for cooking. However, biogas being enough or not is affected by so many factors right from adoption, use and management. As already discussed in Section 3.1 pertaining adoption, majority of the surveyed digesters were over designed in relation to the family size and one would expect biogas to be more than enough even if no energy saving practices are applied, which is not the case. To understand this anomaly, the next section of management and operation of biogas digesters is important.

\subsection{Technical Factors That Influence Biogas Performance at Management Level}

Figure 5 presents results on who feeds the digester, how much and how often is the digester fed and what ratios of water to feedstock that are used. Again like in 


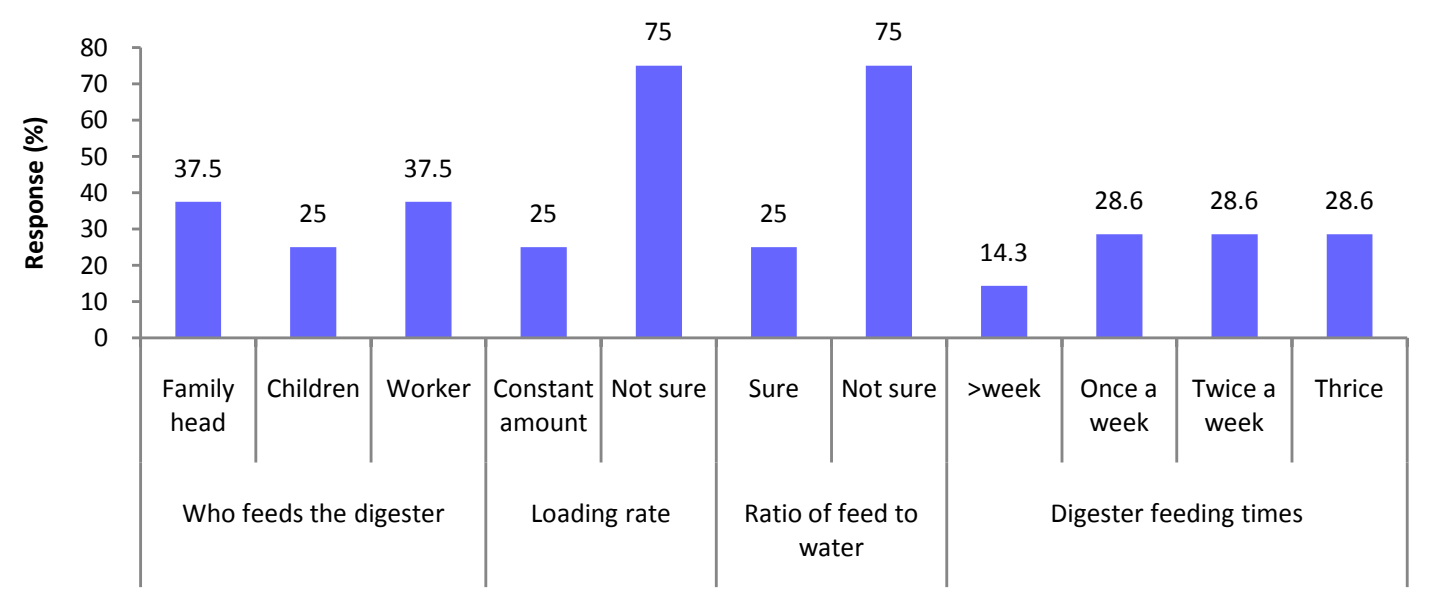

Figure 5. Biogas digester management practices hindering performance.

Section 3.2, the question on who feeds the digesters was meant to capture the level of risk associated with less responsible people who may not know the impact of changing defined parameters. Feeding a biogas digester is a dirty activity that follows specified guidelines which requires someone responsible and knowledgeable. Therefore, assigning children or workers to feed the digester daily may require supervision occasionally. In regard to the how much question, which refers to an important parameter of loading rate, $75 \%$ of the households were not sure of how much the feed the digester per unit time. Only $25 \%$ was in position to specify the quantity in terms of wheel borrows. The size and performance of any digester are based on the loading rate. There is a lot of literature showing the effect of loading rate on digester performance [15] [16] [17] [18]. If $75 \%$ of the surveyed households are not sure of how much they feed into the digester per unit time, then, the efficiency becomes unpredictable.

Similarly, $75 \%$ of the households were not sure of the mixing ratio of water to feedstock. Equally so, this affects digester performance as concentrated mixture or feed slow down the anaerobic digestion process while over diluted feed is associated with scum formation [5]. There must be a dilution consistency for every type of feedstock and depending on its state. This information can only be made know to biogas end-users by researchers or energy extension workers who are nowhere in adoption, use and management of biogas systems.

Like most of the questions, the question on how often the digesters are fed was an open ended one. Respondents gave varying responses like once in 2 days, once in 3 days, on every Sunday to mention but a few. These responses were then categorized into more than a week, once a week, twice a week and thrice a week. From Figure 5, those that feed once, twice and thrice a week were represented by $28.6 \%$ for each category. On the other hand, those who take more than a week were represented by $14.3 \%$. A biogas digester is expected to be fed daily [5] [19], but among the surveyed digesters none was being fed on a daily basis. This factor of feeding the digester daily is closely related to the digester size as well as loading rate. From hydraulic retention time (HRT) given as the ratio of the active digester volume to the daily loading rate or daily outflow, where HRT 
determines the time available for microorganisms to grow and multiply and the time when the substrate is converted to biogas, the effect of not feeding biogas digester daily can be explained. Using the an approximate amount of 280 litres of feedstock mixture per unit time and feeding a digester of $8 \mathrm{~m}^{3}$ once in three days as given by one the respondents, the HRT approximates to 60 days assuming the active volume of the digester is two thirds. One who feeds once in two days, HRT approximates to 40 days while one who feed once a week, HRT approximates to 140 days. However, if they were feeding daily HRT would be 20 days. Literature presents varying ranges of HRT for household biogas digesters. [5] suggested HRT of 20 to 60 days while [20] suggested HRT of 30 to 50 days. However, these ranges are based on digesters fed on a daily basis. It can therefore be said that the surveyed digesters were designed for a HRT of 20 days but the users are operating at HRTs of 40,60,140 days and above. This leads to less biogas being produced as the material takes a lot of time to come out of the digester when it has already been used up by microorganisms. This is because biogas production from any substrate follows the first order reaction or a sigmoid curve as time increases. Analogous to this scenario is where one fails to feed his animal for two or more days and on the third day gives it the quantity of food it would have eaten in three days expecting it to eat all. In biogas digesters, this is over loading and results into digester instability. This can be termed as a

"starvation-over feeding problem". It is therefore no surprise that $87.5 \%$ of the respondents, biogas was not enough. At this level of biogas operation and management, the user will never know the significance of loading rate, dilution consistency and HRT unless researchers are involved in the implementation and monitoring processes of biogas projects. There is therefore need to retrain biogas end-users on biogas digester use and management practices that enhance performance for biogas to be sufficient as well as establishing regional biogas monitoring centres.

\subsection{Implications on the Future of Household Biogas Digesters}

Having presented technical factors affecting biogas right from adoption through use to management, this section presents the implications of these factors on the future of household biogas digesters. From adoption, it was shown that all the digesters under use were of the Chinese fixed dome type. This type of digester requires a big space and probably this could be one of the factors why only three digesters were found in the two selected divisions in Kampala city where space is limited than the other sub-counties in Wakiso district which are just beginning to be occupied (Figure 1). As urbanisation areas grow, there will be need for change in the design and type of digester currently used given space constraints. Otherwise, there will be limited options for those who may want to adopt as they will be lacking enough space. Figure 6 shows the rate of adoption for the surveyed digesters. It can be seen that $50 \%$ were constructed in 2009 and for the following three years, the rate dropped to $12.5 \%$. Though, there are many factors responsible for this decline, if a technology is working, one would expect some 


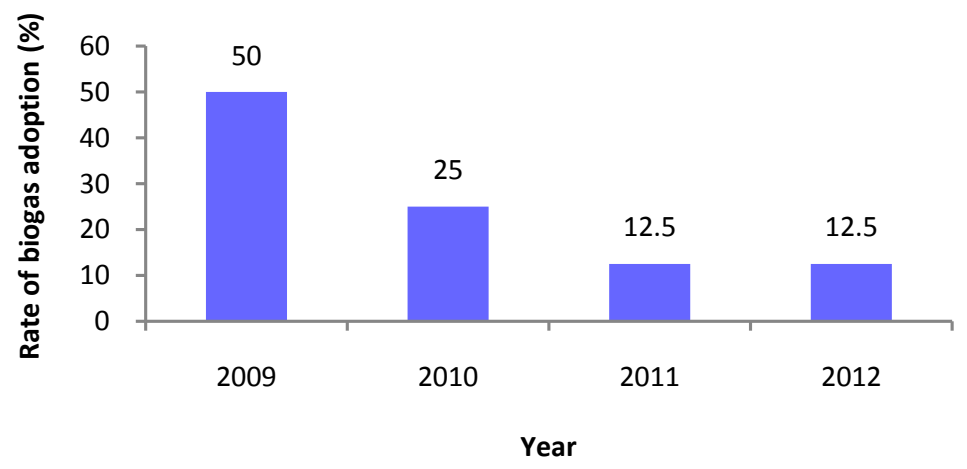

Figure 6. Rate of biogas adoption.

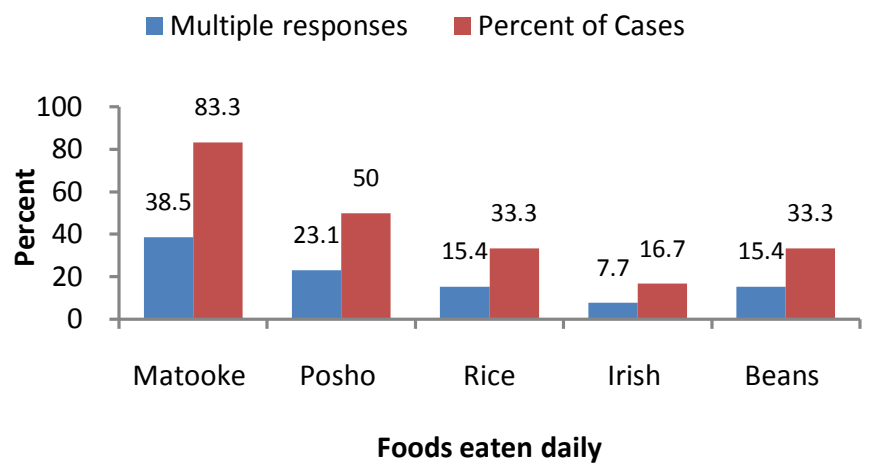

Figure 7. Foods eaten on daily basis by biogas household owners in Kampala peri-urban areas.

positive trend. However, the limiting factor is the reliance on cow dung as the main feedstock which even from the survey is responsible for abandoning a working digester after the death of animals. Several researchers have suggested diversification of biogas feedstock by exploiting household waste. Figure 7 presents the percentage share of what the households surveyed eat on a daily basis. Matooke came on top with over $80 \%$ on case basis and $38 \%$ for multiple responses. These findings on matooke agree with other researchers' finding who found matooke peels as the most dominant organic waste in Kampala municipal solid waste and on landfills [21] [22] [23]. Therefore, redesigning the digesters to take advantage of this available household agricultural waste would not only solve the over design problem which is associated with low performance but would attract other households without animals. However, researchers are needed in this area to make it work. By introducing biogas, the hope was to reduce or eliminate the use of wood fuel at household level. Nevertheless, Figure 8 shows that the situation is still far from reality as wood fuel is still dominating in $90 \%$ of households with biogas digesters. As already suggested above, this can be solved by redesigning the digesters, feedstock or substrate diversification and retraining biogas end-users on use and management. Without going back to the drawing board where policy makers, social workers, economists, scientists, technicians and users come together, the situation is likely even to go back as it used to be before the introduction of biogas programme. This is because the factors 


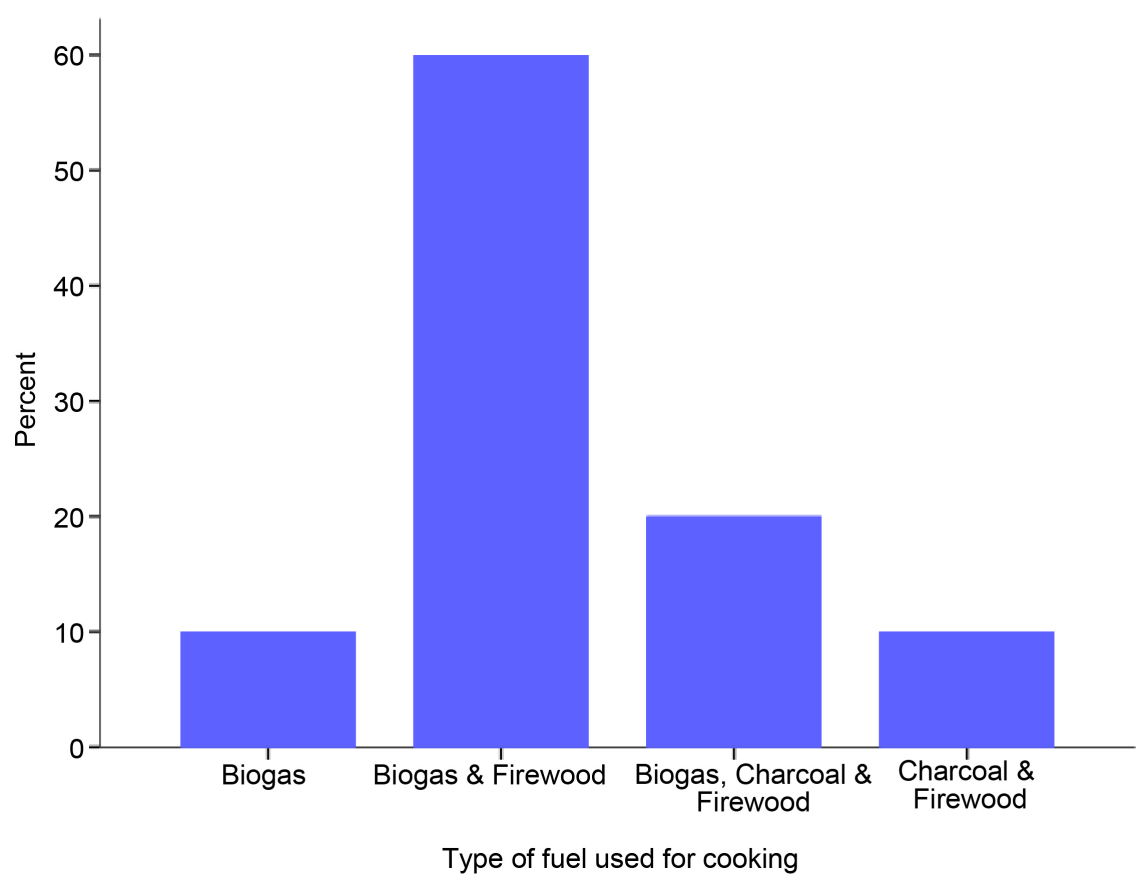

Figure 8. Fuel types used for cooking in households with biogas digesters.

that have been presented in this work are not to be blamed on the end-user nor the technician but on all stakeholders. This therefore, calls for extension workers not necessarily in agriculture alone but in energy saving and performance efficiency areas.

\section{Conclusion}

There is a need for a shift from the common fixed dome type of digester to small and compact types which do not require large spaces in addition to substrate diversification and process optimisation and control. Majority of the household biogas digesters are over designed and cannot adapt to any unexpected reduction in feedstock supply. Over $70 \%$ of biogas users were found not to know how much is needed to feed their digesters and mixing ratios. This is not to mention that none was found to be feeding the digester daily. All this coupled with the oversize problem seem to be the major causes of why biogas is not enough for 87.5\% of the households and responsible for the situation presented in Figure 8 . For the purpose for which biogas technology was introduced to be realized, there is a need for all stakeholders in biogas to come together to address these challenges. Otherwise, the situation is likely to go back to where it used to be before biogas.

\section{Acknowledgements}

This research was funded by the Office of Research and Development (ORD) University of Botswana and Support made possible through a capacity building competitive grant Training the next generation of scientists provided by Carnegie Cooperation of New York through the Regional Universities Forum for Ca- 
pacity Building in Agriculture (RUFORUM). Peter is a METEGA sponsored graduate student at University of Botswana.

\section{References}

[1] Mwirigi, J., Balana, B., Mugisha, J., Walekhwa, P., Melamu, R., Nakami, S. and Makenzi, P. (2014) Socio-Economic Hurdles to Widespread Adoption of Small-Scale Biogas Digesters in Sub-Saharan Africa: A Review. Biomass and Bioenergy, 70, 1725. https://doi.org/10.1016/j.biombioe.2014.02.018

[2] Parawira, W. (2009) Biogas Technology in Sub-Saharan Africa: Status, Prospects and Constraints. Reviews in Environmental Science and Biol Technology, 8, 187200. https://doi.org/10.1007/s11157-009-9148-0

[3] Tumwesige, V., Fulford, D. and Davidson, G.C. (2014) Biogas Appliances in SubSahara Africa. Biomass and Bioenergy, 70, 40-50.

https://doi.org/10.1016/j.biombioe.2014.02.017

[4] Sserunjoji (2014) Is Uganda Prepared for the Looming Charcoal Crisis? Daily Monitor News Paper, Daily Monitor, Kampala-Uganda.

[5] Rajendran, K., Aslanzadeh, S. and Taherzadeh, M.J. (2012) Household Biogas Digesters-A Review. Energies, 5, 2911-2942. https://doi.org/10.3390/en5082911

[6] Balana, B.B. and Glenk, K. (2011) The Potential of Small-Scale Biogas Digesters to Alleviate Poverty and Improve Long Term Sustainability of Ecosystem Services in Sub-Saharan Africa. DFID NET-RCA06502.

[7] Chen, Y., Yang, G., Sweeney, S. and Feng, Y. (2010) Household Biogas Use in Rural China: A Study of Opportunities and Constraints. Renewable and Sustainable Energy Reviews, 14, 545-549. https://doi.org/10.1016/j.rser.2009.07.019

[8] Han, J., Mol, A.P., Lu, Y. and Zhang, L. (2008) Small-Scale Bioenergy Projects in Rural China: Lessons to Be Learnt. Energy Policy, 36, 2154-2162. https://doi.org/10.1016/j.enpol.2008.03.001

[9] Song, Z., Zhang, C., Yang, G., Feng, Y., Ren, G. and Han, X. (2014) Comparison of Biogas Development from Households and Medium and Large-Scale Biogas Plants in Rural China. Renewable and Sustainable Energy Reviews, 33, 204-213. https://doi.org/10.1016/j.rser.2014.01.084

[10] Subedi, M., Matthews, R., Pogson, M., Abegaz, A., Balana, B., Oyesiku-Blakemore, J. and Smith, J. (2014) Can Biogas Digesters Help to Reduce Deforestation in Africa? Biomass and Bioenergy, 70, 87-98. https://doi.org/10.1016/j.biombioe.2014.02.029

[11] Bond, T. and Templeton, M.R. (2011) History and Future of Domestic Biogas Plants in the Developing World. Energy for Sustainable Development, 15, 347-354.

[12] Angelidaki, I. and Ellegaard, L. (2003) Codigestion of Manure and Organic Wastes in Centralized Biogas Plants. Applied Biochemistry and Biotechnology, 109, 95-105. https://doi.org/10.1385/ABAB:109:1-3:95

[13] Ward, A.J., Hobbs, P.J., Holliman, P.J. and Jones, D.L. (2008) Optimisation of the Anaerobic Digestion of Agricultural Resources. Bioresource Technology, 99(17), p. 7928-7940. https://doi.org/10.1016/j.biortech.2008.02.044

[14] El-Mashad, H.M. and Zhang, R. (2010) Biogas Production from Co-Digestion of Dairy Manure and Food Waste. Bioresource Technology, 101, 4021-4028. https://doi.org/10.1016/j.biortech.2010.01.027

[15] Alvarez, R. and Lidén, G. (2008) Semi-Continuous Co-Digestion of Solid Slaughterhouse Waste, Manure, and Fruit and Vegetable Waste. Renewable Energy, 33, 726-734. https://doi.org/10.1016/j.renene.2007.05.001 
[16] Ganesh, R., Torrijos, M., Sousbie, P., Steyer, J.P., Lugardon, A. and Delgenes, J.P. (2013) Anaerobic Co-Digestion of Solid Waste: Effect of Increasing Organic Loading Rates and Characterization of the Solubilised Organic Matter. Bioresource Technology, 130, 559-569. https://doi.org/10.1016/j.biortech.2012.12.119

[17] Gómez, X., Cuetos, M.J., Cara, J., Morán, A. and García, A.I. (2006) Anaerobic Co-Digestion of Primary Sludge and the Fruit and Vegetable Fraction of the $\mathrm{Mu}$ nicipal Solid Wastes: Conditions for Mixing and Evaluation of the Organic Loading Rate. Renewable Energy, 31, 2017-2024. https://doi.org/10.1016/j.renene.2005.09.029

[18] Karim, K., Hoffmann, R., Klasson, T. and Al-Dahhan, M.H. (2005) Anaerobic Digestion of Animal Waste: Effect of Mode of Mixing. Water Research, 39, 3597-3606. https://doi.org/10.1016/j.watres.2005.06.019

[19] House, D. (2006) Biogas Handbook. Being a Compendium of the Art and Science of Using Anything Once Alive to Produce a Burnable Gas for Powering Light, Automobiles, Ovens. Tractors, Water Heaters, Furnaces and Various Contraptions. Alternative House Information, USA, 285.

[20] Yadvika, Santosh, Sreekrishnan, T.R., Kohli, S. and Rana, V. (2004) Enhancement of Biogas Production from Solid Substrates Using Different Techniques-A Review. Bioresource Technology, 95, 1-10. https://doi.org/10.1016/j.biortech.2004.02.010

[21] Kinobe, J.R., Gebresenbet, G., Niwagaba, C.B. and Vinnerås, B. (2015) Reverse Logistics System and Recycling Potential at a Landfill: A Case Study from Kampala City. Waste Management, 42, 82-92. https://doi.org/10.1016/j.wasman.2015.04.012

[22] Komakech, A.J., Banadda, N.E., Kinobe, J.R., Kasisira, L., Sundberg, C., Gebresenbet, G. and Vinneras, B. (2014) Characterization of Municipal Waste in Kampala, Uganda. Journal of the Air \& Waste Management Association, 64, 340-348. https://doi.org/10.1080/10962247.2013.861373

[23] Banga, M. (2011) Household Knowledge, Attitudes and Practices in Solid Waste Segregation and Recycling: The Case of Urban Kampala. Zambia Social Science Journal, 2, Article 4

\section{Submit or recommend next manuscript to SCIRP and we will provide best} service for you:

Accepting pre-submission inquiries through Email, Facebook, LinkedIn, Twitter, etc. A wide selection of journals (inclusive of 9 subjects, more than 200 journals)

Providing 24-hour high-quality service

User-friendly online submission system

Fair and swift peer-review system

Efficient typesetting and proofreading procedure

Display of the result of downloads and visits, as well as the number of cited articles

Maximum dissemination of your research work

Submit your manuscript at: http://papersubmission.scirp.org/

Or contact cweee@scirp.org 